\title{
Characterization of Suspended Solids and Total Phosphorus Loadings from Small Watersheds in Wisconsin
}

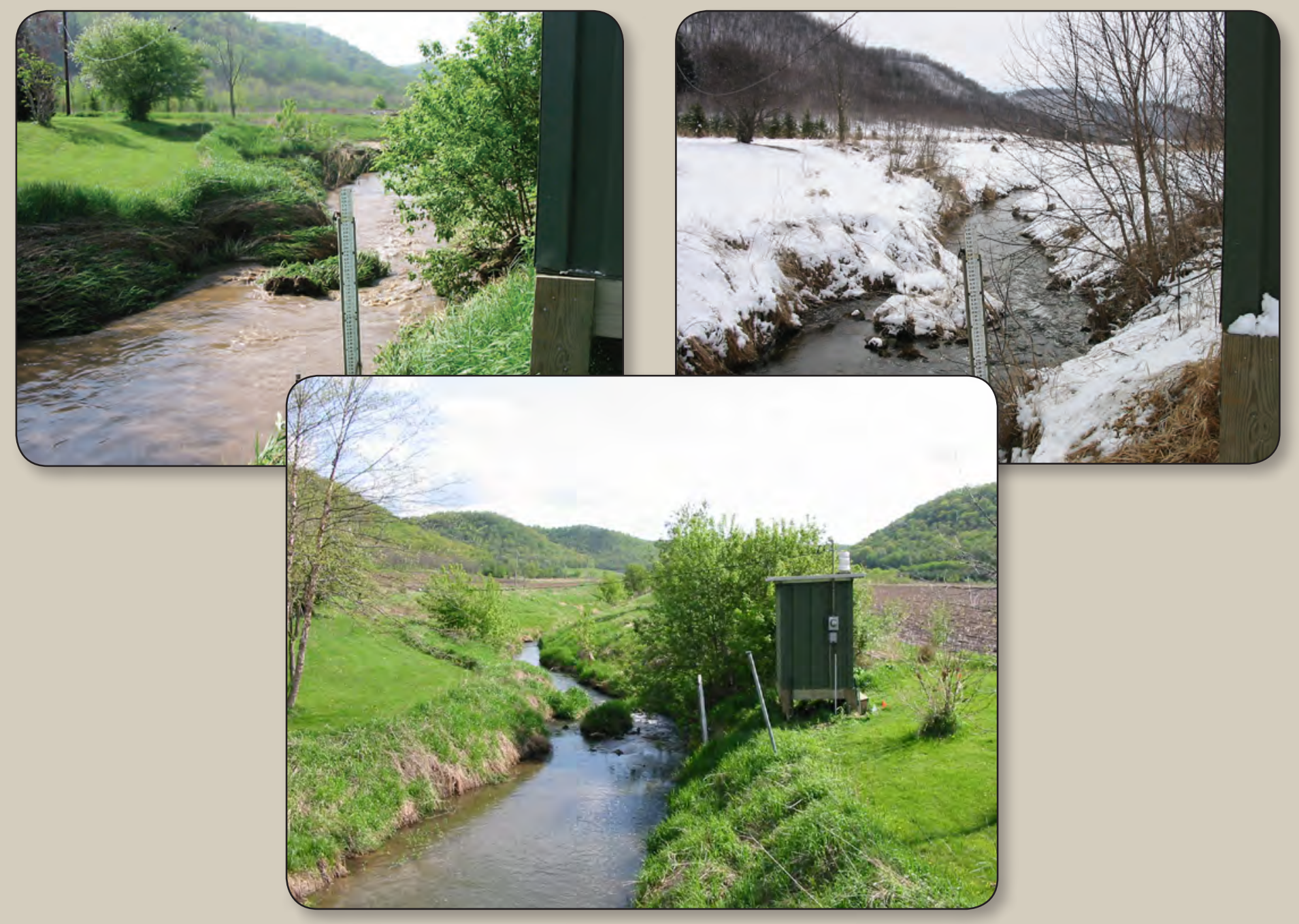

Scientific Investigations Report 2010-5039 
Cover: U.S. Geological Survey gaging station on Eagle Creek near Fountain City, Wisconsin (USGS streamflow-gaging station No. 05378185).

Clockwise from top left:

5/20/2004 Event Photograph by Mari Danz, U.S. Geological Survey

3/15/2006 Winter Photograph by Troy Rutter, U.S. Geological Survey

5/10/2006 Summer Photograph by Troy Rutter, U.S. Geological Survey 


\section{Characterization of Suspended Solids and Total Phosphorus Loadings from Small Watersheds in Wisconsin}

By Mari E. Danz, Steven R. Corsi, and David J. Graczyk, U.S. Geological Survey; and Roger T. Bannerman, Wisconsin Department of Natural Resources

Scientific Investigations Report 2010-5039 


\title{
U.S. Department of the Interior \\ KEN SALAZAR, Secretary
}

\section{U.S. Geological Survey \\ Marcia K. McNutt, Director}

\section{U.S. Geological Survey, Reston, Virginia: 2010}

\author{
For more information on the USGS — the Federal source for science about the Earth, its natural and living resources, \\ natural hazards, and the environment, visit http://www.usgs.gov or call 1-888-ASK-USGS \\ For an overview of USGS information products, including maps, imagery, and publications, \\ visit http://www.usgs.gov/pubprod \\ To order this and other USGS information products, visit http://store.usgs.gov
}

Any use of trade, product, or firm names is for descriptive purposes only and does not imply endorsement by the U.S. Government.

Although this report is in the public domain, permission must be secured from the individual copyright owners to reproduce any copyrighted materials contained within this report.

Suggested citation:

Danz, M.E., Corsi, S.R., Graczyk, D.J., and Bannerman, R.T., 2010, Characterization of suspended solids and total phosphorus loadings from small watersheds in Wisconsin: U.S. Geological Survey Scientific Investigations Report 2010-5039, 16 p. 


\section{Contents}

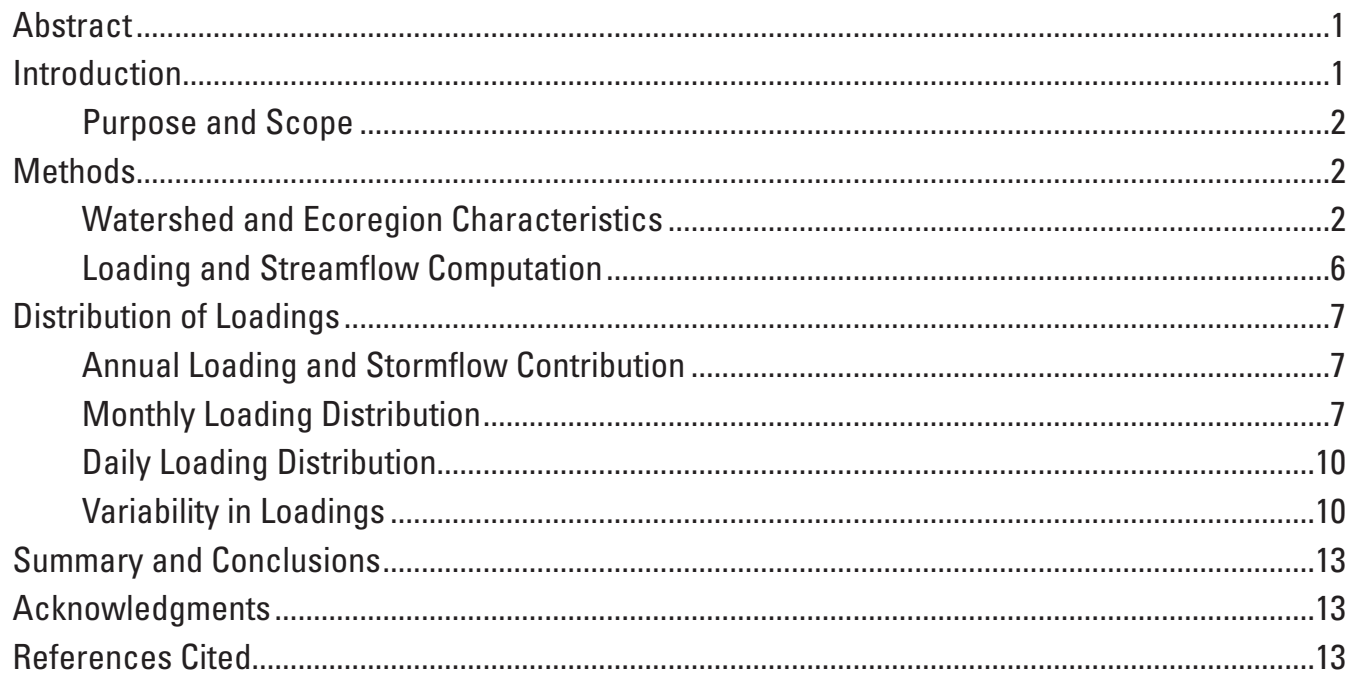

\section{Figures}

Figure 1. Map showing location of selected watersheds and streamflow-gaging stations in Wisconsin

Figure 2. Graphs showing percent of the average annual solids and total phosphorus load and streamflow contributed by stormflow for selected watersheds in Wisconsin

Figure 3. Graphs showing percentage of the average annual solids and total phosphorus loads and average annual streamflow contributed by base flow and stormflow for selected watersheds in Wisconsin, by month

Figure 4. Graphs showing cumulative distribution of ranked daily loading as a percent of annual solids and total phosphorus for selected watersheds in Wisconsin ecoregions.....

Figure 5. Box plots showing distribution of the percent of total solids contributed by stormflow and base flow each month for selected watersheds in the Driftless Area ecoregion of Wisconsin

\section{Tables}

Table 1. Land use, drainage area, and years of record for selected watersheds in Wisconsin 


\section{Conversion Factors and Datum}

Conversion Factors

\begin{tabular}{lcl}
\hline \multicolumn{1}{c}{ Multiply } & By & \multicolumn{1}{c}{ To obtain } \\
\hline mile $(\mathrm{mi})$ & 1.609 & kilometer $(\mathrm{km})$ \\
square mile $\left(\mathrm{mi}^{2}\right)$ & 2.590 & square kilometer $\left(\mathrm{km}^{2}\right)$ \\
\hline
\end{tabular}

Datum

Horizontal coordinate information is referenced to the North American datum of 1983 (NAD 83). 


\title{
Characterization of Suspended Solids and Total Phosphorus Loadings from Small Watersheds in Wisconsin
}

\author{
By Mari E. Danz', Steven R. Corsi', David J. Graczyk', and Roger T. Bannerman ${ }^{2}$
}

\section{Abstract}

Knowledge of the daily, monthly, and yearly distribution of contaminant loadings and streamflow can be critical for the successful implementation and evaluation of water-quality management practices. Loading data for solids (suspended sediment and total suspended solids) and total phosphorus and streamflow data for 23 watersheds were summarized for four ecoregions of Wisconsin: the Driftless Area Ecoregion, the Northern Lakes and Forests Ecoregion, the North Central Hardwoods Ecoregion, and the Southeastern Wisconsin Till Plains Ecoregion. The Northern Lakes and Forests and the North Central Hardwoods Ecoregions were combined into one region for analysis due to a lack of sufficient data in each region. Urban watersheds, all located in the Southeastern Wisconsin Till Plains, were analyzed separately from rural watersheds as the Rural Southeastern Wisconsin Till Plains region and the Urban Southeastern Wisconsin Till Plains region. Results provide information on the distribution of loadings and streamflow between base flow and stormflow, the timing of loadings and streamflow throughout the year, and information regarding the number of days in which the majority of the annual loading is transported.

The average contribution to annual solids loading from stormflow periods for the Driftless Area Ecoregion was 84 percent, the Northern Lakes and Forests/North Central Hardwoods region was 71 percent, the Rural Southeastern Wisconsin Till Plains region was 70 percent, and the Urban Southeastern Wisconsin Till Plains region was 90 percent. The average contributions to annual total phosphorus loading from stormflow periods were $72,49,61$, and 76 percent for each of the respective regions. The average contributions to annual streamflow from stormflow periods are 20, 23, 31, and 50 percent for each of the respective regions.

In all regions, the most substantial loading contributions for solids were in the late winter (February through March), spring (April through May), and early summer (June through

\footnotetext{
${ }^{1}$ U.S. Geological Survey, Middleton, Wisconsin

${ }^{2}$ Wisconsin Department of Natural Resources, Madison, Wisconsin
}

July), with fall (October through November) and early winter (December through January) contributing the smallest loadings. The Northern Lakes and Forests/North Central Hardwoods region had some substantial loading in September. There was a similar pattern for total phosphorus loading in all regions, with the pattern somewhat less pronounced in urban watersheds. As with the loading results, average monthly streamflow values were greatest in late winter, spring, and early summer, with the lowest values typically in fall and early winter. Loading contributions were greater from stormflow than from base flow in all instances, except total phosphorus in the Northern Lakes and Forests/North Central Hardwoods region, which had equal or greater base-flow contribution for several months. Base flow constituted a greater percentage of the total streamflow than stormflow in all rural watersheds for all regions.

Only a few storms each year dominated the annual loading totals for solids and total phosphorus. When daily loading values were ranked for the year, all regions reached 50 percent of the annual solids loading in the 5 highest loading days and nearly 50 percent of the annual total phosphorus loading in the 14 highest loading days.

\section{Introduction}

Federal, State, and local watershed managers and scientists use loading estimates of solids and total phosphorus in streams for numerous management purposes. Loading data are the foundation upon which water-quality management practices are built. Loading data are used to establish goals for reducing contaminant loadings, to estimate the relative magnitude of nonpoint sources compared to point sources, and to estimate nutrient loadings to lakes (Lathrop and others, 1998; Lathrop and others, 2007). Information on total loading potential is important in designing and evaluating water-quality management practices (Corsi and others, 1997). Further information on the seasonal timing and distribution of loadings could provide valuable insight for watershed managers to accomplish these water-quality management actions. 
The effectiveness of management practices for improving water quality can be influenced by hydrologic conditions as well as the timing and relative magnitude of loading contributions throughout the year (Stuntebeck and Bannerman, 1998; Corsi and others, 2005). Therefore, an understanding of the temporal distribution of loading contributions is critical in the design and evaluation of these practices. Some management practices may function successfully only during certain times of the year. For example, if the majority of the annual loading is transported during periods when the ground is frozen, the effectiveness of management techniques that rely on emergent vegetation may be reduced. These seasonal issues can affect the evaluation and monitoring of management practices as well. For example, if the majority of the loading is transported during winter months (December through March), the monitoring plan needs to be designed for sampling during snowmelt periods.

Many management practices are designed specifically for controlling nonpoint pollution during storm-runoff periods (Graczyk and others, 2003). Quantification of the fraction of loading contributed during storm runoff, as opposed to that contributed during base-flow periods, can provide important information on potential loading reductions.

To effectively design, implement, and evaluate the effects of management practices, determination of the number of days that contribute the majority of the annual loading is also important. If a substantial proportion of the annual loading is transported during a few days that have large runoff events, management practices would need to be designed to accommodate a large volume of water. In addition, the monitoring plan would need to include sampling activities that will ensure accurate concentration estimates for high-flow events as well as for base-flow periods in order to adequately estimate annual loadings.

The U.S. Geological Survey (USGS) has monitored water quality in many watersheds throughout Wisconsin in cooperation with national, regional, State, and local agencies. Solids and total phosphorus are the two most commonly recognized and monitored nonpoint contaminants with elevated concentrations resulting from agricultural and urban runoff. Solids data collected from USGS monitored watersheds are represented as suspended-sediment concentration or total suspended solids. Analytical methods for determination of suspended-sediment concentration and total suspended solids are different. For water samples that contain large particles (sand size or greater), the reported value of total suspended solids may be slightly less than the value reported for total suspended sediment. For the purposes of this report, however, the two constituents are considered to be interchangeable and will be referred to as "solids" throughout the report.

\section{Purpose and Scope}

This report presents the results of a study conducted by the U.S. Geological Survey in cooperation with the Wisconsin Department of Natural Resources (WDNR). The objective of this report is to provide Wisconsin water-resource managers with information describing the daily, monthly, and yearly distributions of solids and total phosphorus loadings and streamflow. This report examines these distributions and relative magnitudes of loading occurrence. Annual stormflow and base-flow contributions, monthly stormflow and baseflow distributions, and cumulative daily loadings are analyzed and summarized. The information in this report is compiled from data from 23 watersheds throughout Wisconsin that are grouped into regions based on ecoregion and land-use characteristics. The period of record used at each watershed varies between 1 and 29 full water years ${ }^{1}$ for solids and between 1 and 23 full water years for total phosphorus. The data collection occurred between 1976 and 2006. The analysis took place in 2007 and 2008.

\section{Methods}

Daily loading and daily streamflow data were used as the base data for all calculations presented in this report. In order to capture the various ways loading distributions can be characterized, an array of basic statistical analyses were performed on the data. The data were separated into groups likely to have similar trends by summarizing them by ecoregion and land use.

\section{Watershed and Ecoregion Characteristics}

A total of 23 small watersheds throughout Wisconsin were chosen for loading characterization (fig. 1, table 1). Because land use, geologic setting, geographic location, slope, soil type, and climate are factors that can affect the magnitude and variability of loadings, watersheds were grouped and summarized based on the ecoregions of Wisconsin (Omernik and Gallant, 1988). The four main ecoregions of Wisconsin are the Driftless Area Ecoregion, the Northern Lakes and Forests Ecoregion, the North Central Hardwoods Ecoregion, and the Southeastern Wisconsin Till Plains Ecoregion (fig. 1). These ecoregions are defined based on land use, potential natural vegetation, land-surface form, soils, climate, and growing season.

\footnotetext{
${ }^{1}$ A water year is defined as the 12-month period from October 1, for any given year, through September 30, of the following year. The water year is designated by the calendar year in which it ends. Annual references in this report refer to the water year.
} 


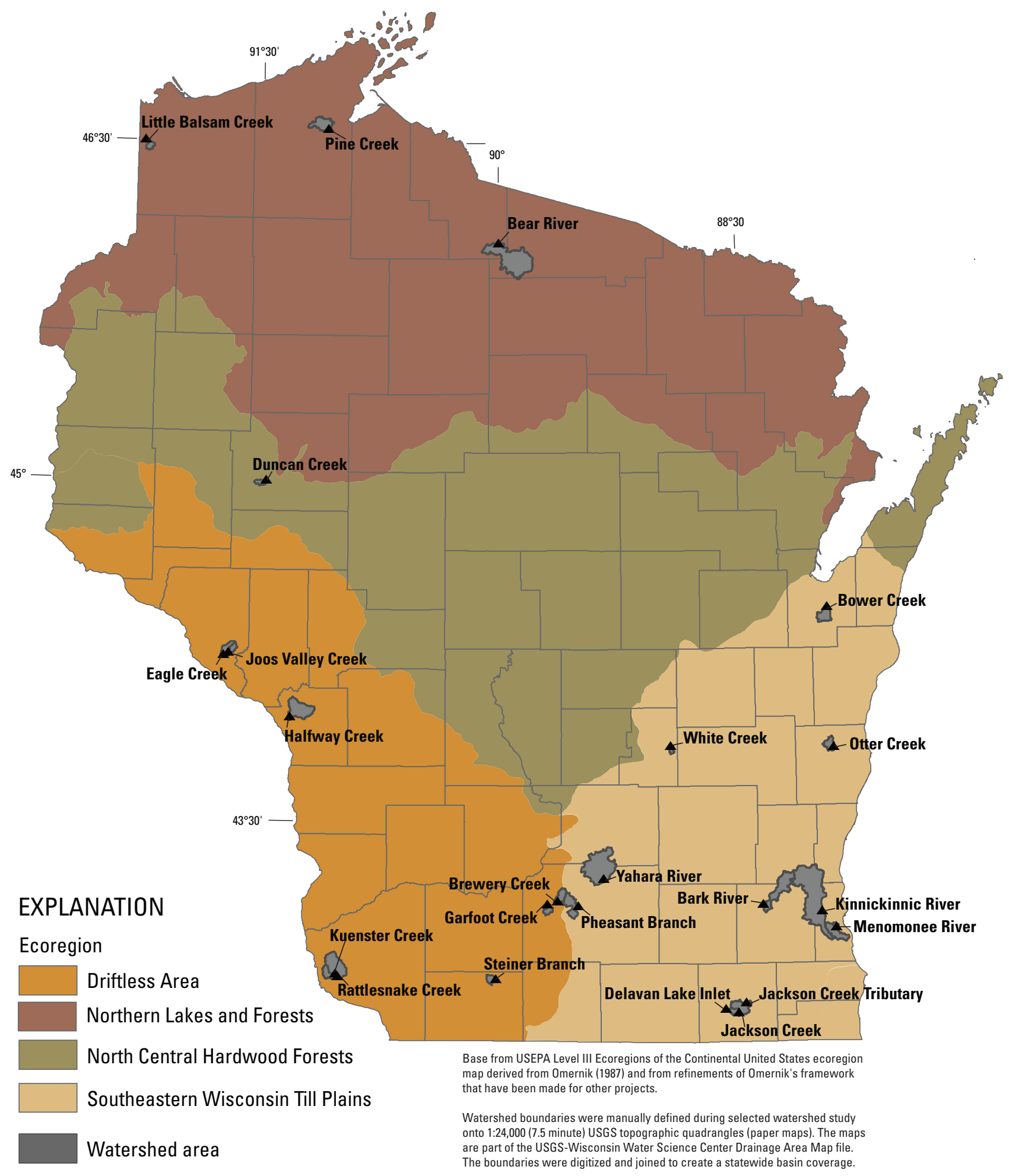

- U.S. Geological Survey gaging station

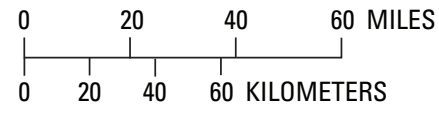

Figure 1. Location of selected watersheds and streamflow-gaging stations in Wisconsin. 
Table 1. Land use, drainage area, and years of record for selected watersheds in Wisconsin.

[ -- , no data available ]

\begin{tabular}{|c|c|c|}
\hline $\begin{array}{l}\text { U.S. Geological Survey } \\
\text { downstream order number }\end{array}$ & Watershed and monitoring station name & $\begin{array}{l}\text { Drainage area } \\
\text { (square miles) }\end{array}$ \\
\hline \multicolumn{3}{|c|}{ Driftless Area Ecoregion } \\
\hline 05406470 & Brewery Creek at Cross Plains & 10.5 \\
\hline 05378185 & Eagle Creek at County Highway G near Fountain City & 14.3 \\
\hline 05406491 & Garfoot Creek near Cross Plains & 5.39 \\
\hline 05382240 & Halfway Creek at County Highway ZN near Onalaska & 34.1 \\
\hline 05378183 & Joos Valley Creek near Fountain City & 5.89 \\
\hline 054134435 & Kuenster Creek at Muskellunge Road near North Andover & 9.59 \\
\hline 05413449 & Rattlesnake Creek near North Andover & 42.4 \\
\hline 05433510 & Steiner Branch near Waldwick & 5.9 \\
\hline \multicolumn{3}{|c|}{ Northern Lakes and Forests Ecoregion/North Central Hardwood Forests Ecoregion } \\
\hline 05357335 & Bear River near Manitowish Waters & 81.3 \\
\hline 05364850 & Duncan Creek Tributary near Tilden & 4.17 \\
\hline 04024314 & Little Balsam Creek at Patzau & 5 \\
\hline 04026349 & Pine Creek near Moquah & 21.5 \\
\hline \multicolumn{3}{|c|}{ Southeastern Wisconsin Till Plains Ecoregion (Rural Watersheds) } \\
\hline 05426067 & Bark River at Nagawicka Road at Delafield & 35.9 \\
\hline 04085119 & Bower Creek at County Trunk Highway MM near De Pere & 14.8 \\
\hline 05431017 & Delavan Lake Inlet at State Highway 50 at Lake Lawn & 21.8 \\
\hline 05431016 & Jackson Creek at Mound Road near Elkhorn & 16.8 \\
\hline 040857005 & Otter Creek at Willow Road near Plymouth & 9.5 \\
\hline 04073462 & White Creek at Spring Grove Road near Green Lake & 3.05 \\
\hline 05427718 & Yahara River at Windsor & 73.6 \\
\hline \multicolumn{3}{|c|}{ Southeastern Wisconsin Till Plains Ecoregion (Urban Watersheds) } \\
\hline 054310157 & Jackson Creek Tributary near Elkhorn & 4.34 \\
\hline 04087159 & Kinnickinnic River at S. 11th Street at Milwaukee & 18.8 \\
\hline 04087120 & Menomonee River at Wauwatosa & 123 \\
\hline 05427948 & Pheasant Branch at Middleton & 18.3 \\
\hline
\end{tabular}




\section{Full years of record}

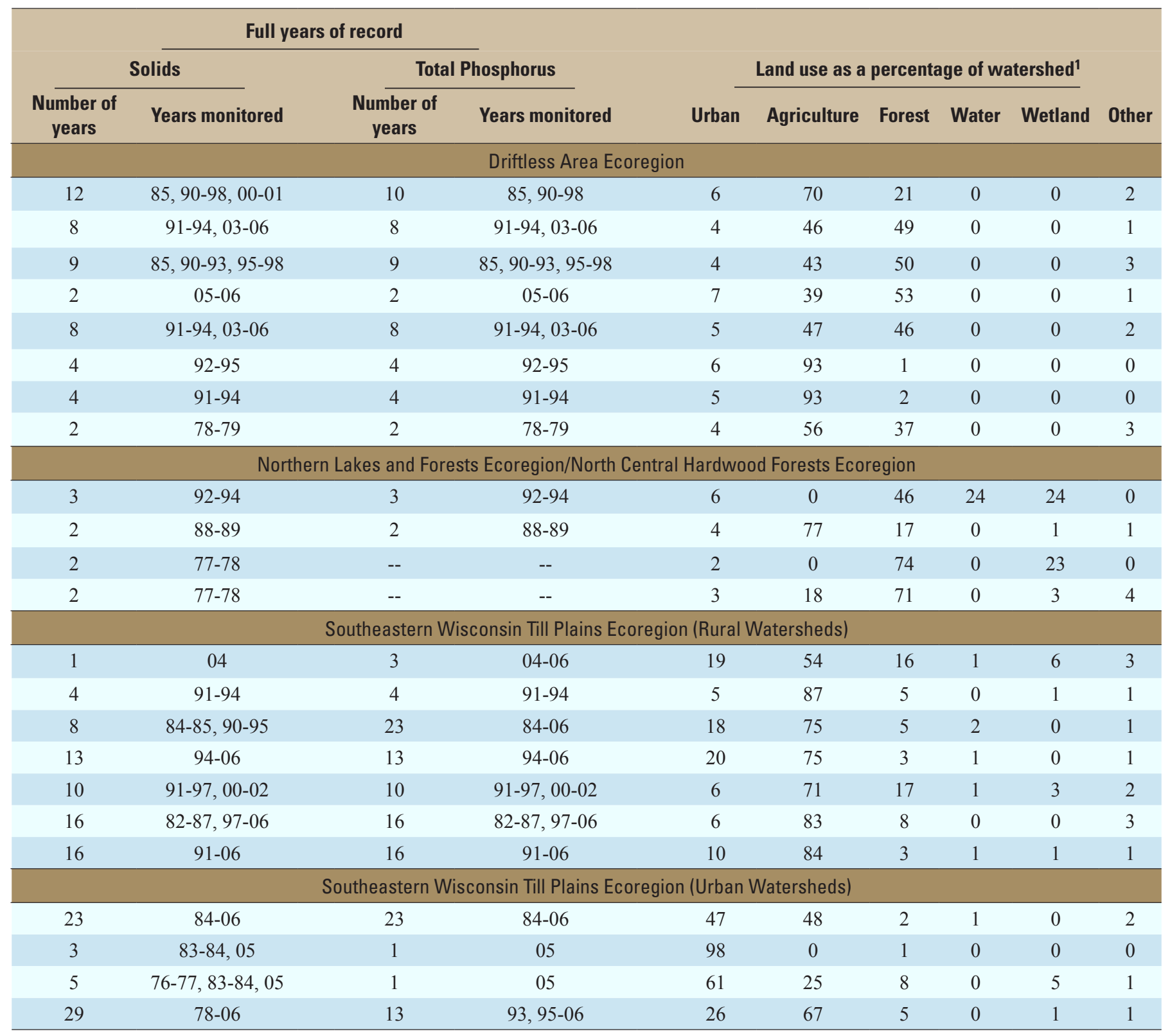

\footnotetext{
${ }^{1}$ Land cover was derived for watersheds from the National Land Cover Data Set (NLCD) using a geographic information system (GIS) (Homer and others,
} 2007; U.S. Geological Survey, 2008). 
Due to a lack of qualifying streamflow-gaging and water-quality monitoring stations available in the northern ecoregions, the data from the selected watersheds in the Northern Lakes and Forests Ecoregion and the North Central Hardwoods Ecoregion were combined. These two ecoregions have similarities in their soils, land use, vegetation and inclusion of numerous wetland areas. The major differences between the two are that the Northern Lakes and Forest Ecoregion has less agriculture, more wetlands, larger watersheds, and more coniferous forests. The North Central Hardwood Forests Ecoregion is a transitional area between the Northern Lakes and Forests Ecoregion and the highly agricultural ecoregions of the southern part of the state.

Wang and others (1997) have indicated a degradation of biota for Wisconsin streams in watersheds with greater than 10 - to 20-percent urban land use. To address this, land-use data were compiled for each watershed (table 1) and watersheds with greater than 20-percent urban land use were grouped and analyzed separately. All of the watersheds that met these criteria were located within the Southeastern Wisconsin Till Plains Ecoregion.

Throughout the report, the four regions that are analyzed are the Driftless Area Ecoregion, the Northern Lakes and Forests/North Central Hardwoods region, the Rural Southeastern Wisconsin Till Plains region, and the Urban Southeastern Wisconsin Till Plains region.

To generate valid comparisons, the following criteria were used to select the watersheds:

- Drainage area was less than 200 square miles;

- Two or more years of continuous loading data were available for solids or total phosphorus;

- Watersheds were chosen from each of the four regions; and

- Loads were previously published in USGS WaterResources Data Annual Reports.

Watershed boundaries were digitized from 1:24,000 USGS topographic quadrangles and land cover was derived for watersheds from the National Land Cover Database (NLCD) using a geographic information system (GIS) (Homer and others, 2007; U.S. Geological Survey, 2008).

\section{Loading and Streamflow Computation}

Daily loading and daily streamflow values were used for all calculations presented in this report. Each watershed and its associated data are represented in USGS databases and published in "Water Resources Data, Wisconsin" for suspended sediment concentration or total suspended solids, and total phosphorus loadings (U.S. Geological Survey, 1977-1982; Holmstrom and others, 1983-2000; Garn and others, 2001; Waschbusch and others, 2002-2006; and U.S. Geological Survey, 2007).

Loadings of solids and total phosphorus were computed using one of two methods depending on the sampling protocol for each individual sampling site. For most sites, multiple samples were collected during periods of storm runoff, and additional samples were collected during lowflow periods. For these sites, the integration method was used to determine the load for each day and daily loads were summed to determine the annual load (Porterfield, 1972). For the remainder of the sites, multiple samples were collected during each storm runoff period and composited into a single sample; analyses of these composite samples resulted in an "event-mean concentration." Samples also were collected during low-flow periods. "Event loadings" were computed by multiplying the event mean concentrations and the stormflow volumes. The low-flow loadings were computed by use of the integration method. Total loadings were computed by summing the event and low-flow loadings. Streamflow at each site was computed using standard USGS methods (Rantz and others, 1982). Loading and streamflow values were included in this analysis only for water years with complete daily records.

Daily mean streamflow and loadings data were separated into daily mean base-flow and stormflow contributions by use of the USGS Hydrograph Separation Program (HYSEP). This is a computer program that is used to separate a streamflow hydrograph into base-flow and surface-runoff components. It includes three methods of hydrograph separation: the fixedinterval, sliding-interval, and local-minimum methods. These methods can be described conceptually as three different algorithms to systematically draw connecting lines between the low points of the streamflow hydrograph. The sequence of these connecting lines defines the base-flow hydrograph. The hydrograph-separation techniques were developed by Pettyjohn and Henning (1979). The fixed-interval method (Sloto and Crouse, 1996) was used in this report; it assigns the lowest discharge in a calculated time interval to all days in that interval starting with the first day of the period of record. The assigned values are then connected to define the base-flow hydrograph. 


\section{Distribution of Loadings}

Solids, total phosphorus, and streamflow data were analyzed on annual, monthly, and daily time scales. The contributions of these constituents from stormflow and base flow also were analyzed. The following distributions were determined: the distribution of annual loading and streamflow between base flow and stormflow, the monthly distribution of loads and streamflow, and the daily cumulative distribution of loads.

\section{Annual Loading and Stormflow Contribution}

For each of the selected watersheds, the average percentage of annual loading contributed by stormflow was calculated for solids and total phosphorus; the average percentage of total annual streamflow contributed by stormflow also was calculated (fig. 2). For most watersheds, stormflow contribution to total loading is substantially greater than base-flow contribution. For solids, stormflow contributes greater than 50 percent of the loading at 21 of 23 watersheds, greater than 70 percent at 18 watersheds, and greater than 90 percent at 6 watersheds. For total phosphorus, stormflow contributes greater than 50 percent of the loading at 18 of 21 watersheds, greater than 70 percent at 13 watersheds, and greater than 80 percent at 5 watersheds. In contrast, stormflow contribution to total annual streamflow generally is less than base flow. Stormflow contributes less than 50 percent of the annual streamflow at 20 of 23 watersheds, less than 30 percent at 13 watersheds, and less than 20 percent at 9 watersheds. Even though base flow is the major contributor to annual streamflow, the majority of annual constituent load is transported during stormflow periods.

The average contribution to annual solids loading from stormflow periods for the Driftless Area Ecoregion is 84 percent, the Northern Lakes and Forests/North Central Hardwoods region is 71 percent, the Rural Southeastern Wisconsin Till Plains region is 70 percent, and the Urban Southeastern Wisconsin Till Plains region is 90 percent. The average contributions to annual total phosphorus loading from stormflow periods are $72,49,61$, and 76 percent for each of the respective regions. The average contributions to annual streamflow from stormflow periods are 20, 23, 31, and 50 percent for each of the respective regions.

The error bars in figure 2 illustrate the wide variability in stormflow contributions from year to year at individual watersheds. For watersheds with at least 3 years of data, the average maximum-to-minimum range is 31 percent for solids, 33 percent for total phosphorus, and 17 percent for streamflow. Variability among watersheds may be explained by several factors, such as land use, drainage area, slope, soil type, climate, and time period monitored.

\section{Monthly Loading Distribution}

Average monthly percentages of annual loadings and annual streamflow were computed by averaging the percent monthly contributions for all available years at individual watersheds (fig. 3 ). For all rural watersheds, results show substantial solids and total phosphorus loading contributions in the late winter (February through March), spring (April through May), and early summer (June through July), with fall (October through November) and early winter (December through January) contributing the smallest loadings (ig. 3 , rows $\mathrm{A}$ and $\mathrm{B})$. This effect was less pronounced in the urban watersheds, where the total phosphorus loads were distributed more evenly throughout the year (fig. 3 , row B). In the urban watersheds, less than 15 percent of the annual total phosphorus loading was contributed each month. Similar to loading results, average monthly streamflow for rural and urban regions is greatest in late winter, spring, and early summer, with the lowest values typically in fall and early winter (fig. 3, row C). This similarity between loads and streamflow is a result of the direct influence of streamflow on loadings.

These monthly data also were separated into stormflow and base-flow contributions and averaged for each region (fig. 3). Loading contributions were found to be greater from stormflow than from base flow in all instances, except total phosphorus in the Northern Lakes and Forests/North Central Hardwoods region, which has equal or greater base-flow contribution for several months. In contrast, for total streamflow each month, base flow contributes a greater percentage of the monthly streamflow than stormflow in all rural watersheds for all regions. For example, for the Driftless Area Ecoregion, solids loading for March accounts for 22 percent of the total annual solids loading, with 19 percent from stormflow and 3 percent base flow. However, the reverse is true for total streamflow contribution, where March accounts for 13 percent of the total streamflow, with 9 percent from base flow and 4 percent from stormflow. This is a direct result of greater solids and total phosphorus concentrations during stormflow periods than during periods of base flow. In the urban watersheds, where there is more impervious surface area, stormflow and base flow each constitute 50 percent of the streamflow. 


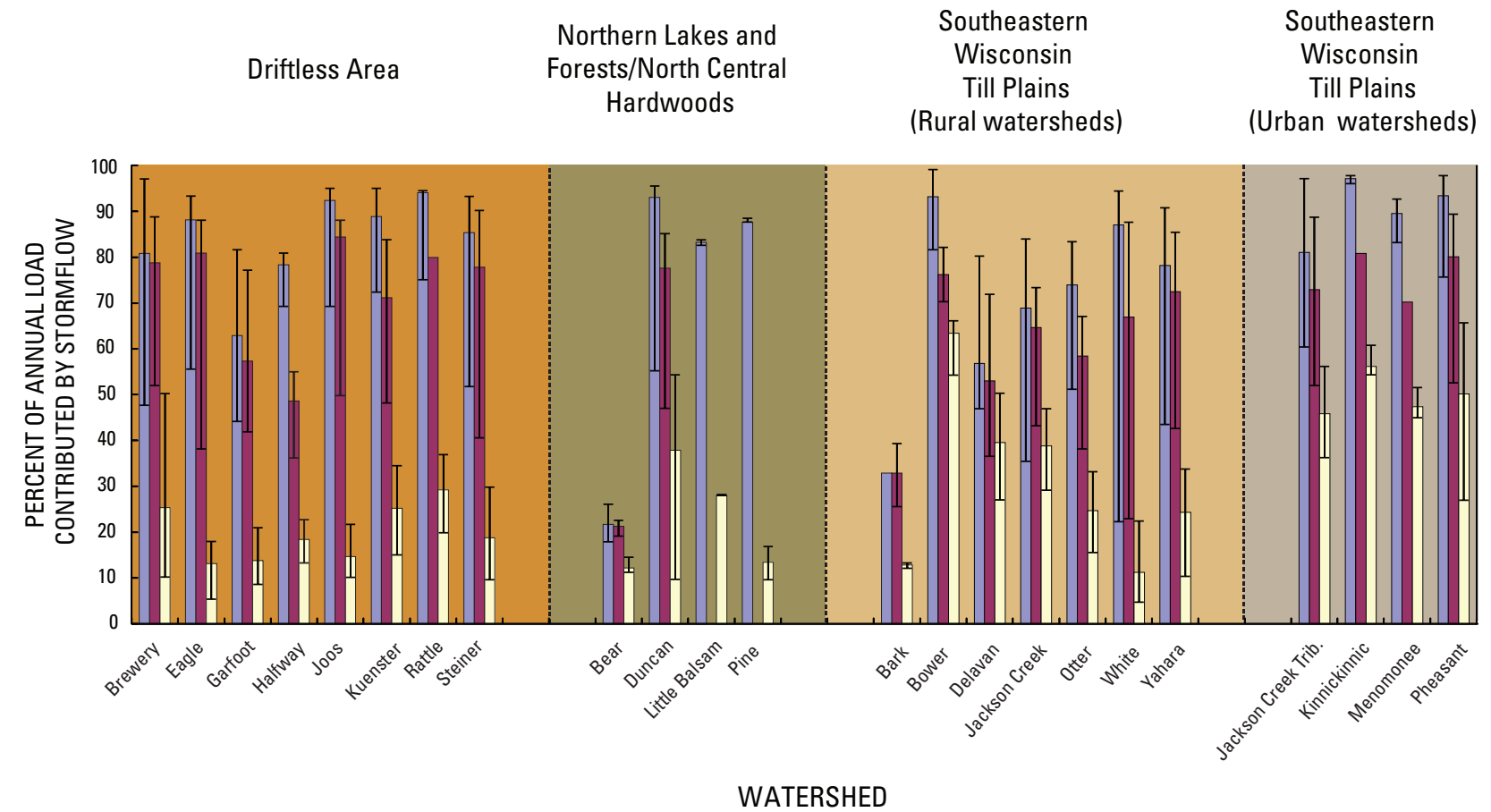

selected watersheds in Wisconsin. 

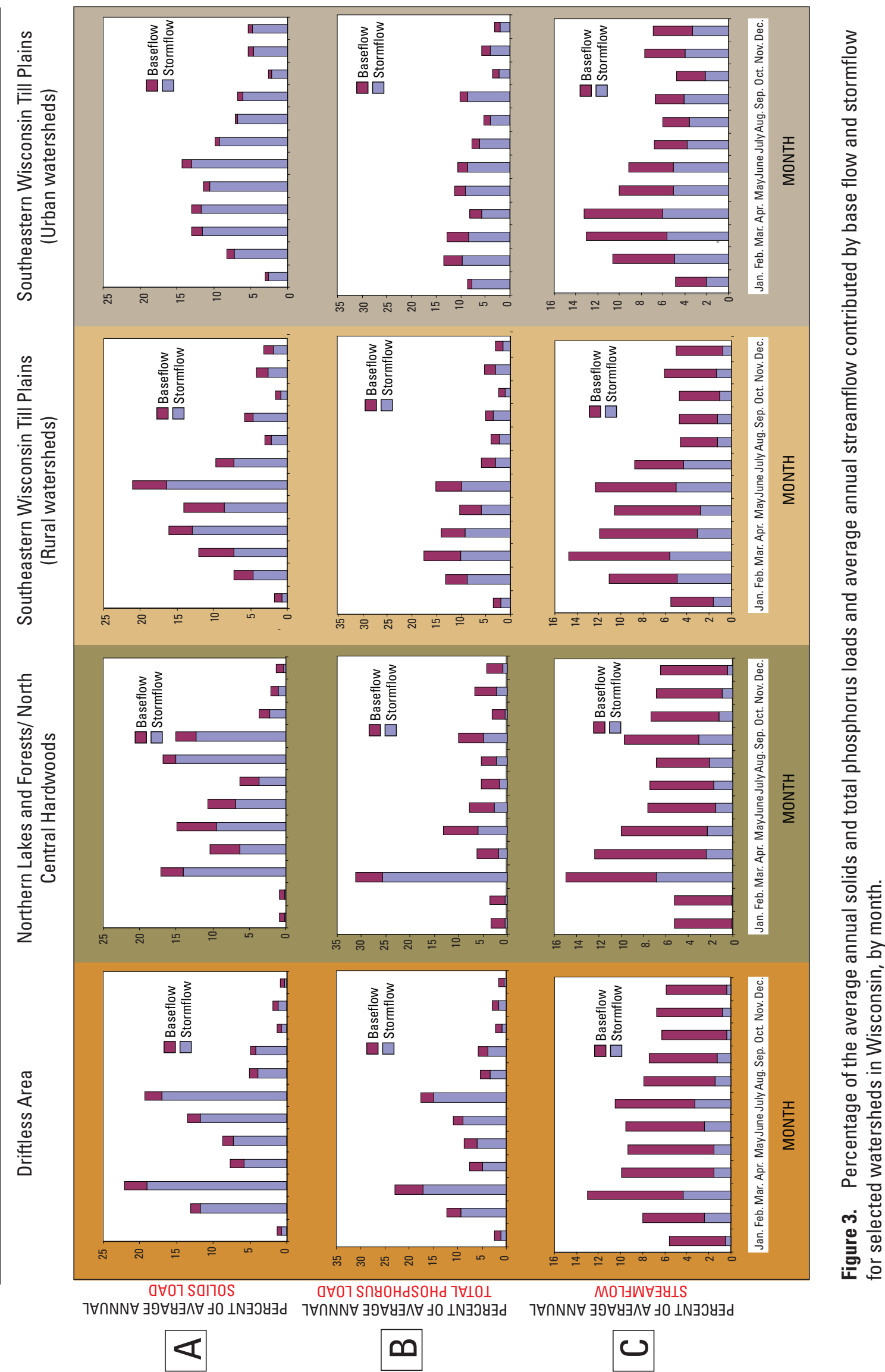


\section{Daily Loading Distribution}

A cumulative distribution of daily constituent loading was determined for each watershed and for each year. For each watershed, the daily loading values were ranked from highest to lowest each year with the greatest value given a ranking of 1 and the smallest value given a ranking of 365 (366 for leap years). A running summation of these values was computed to represent the greatest $1,2,3,4,5,6,7,14,30,60,90,120$, 180,270 , and 365 (annual) day cumulative loadings for each watershed for each year of record. Values were averaged over the period of record and final values were expressed as a percent of the annual loading in each region (fig. 4). The maximum and minimum values from all regions were used to construct cumulative distributions to represent the range of variability (fig. 4).

The magnitude of loading for the first few highest loading days of each curve indicates that a few storms each year dominate the annual loading totals for solids and total phosphorus. All regions reach 50 percent of the annual solids loading in the 5 highest loading days and nearly 50 percent of the annual total phosphorus loading in the 14 highest loading days. Differences among regions are also apparent in these data. For example, the distribution for the Driftless Area Ecoregion, characterized by steeper watersheds, increases more rapidly than other regions for solids and total phosphorus, with 80 percent of the annual solids loading and 69 percent of the annual total phosphorus loading contributed in the 14 highest loading days on average. The solids distribution for the urban watersheds, characterized by more impervious areas, also increases rapidly, with 57 percent of the annual solids loads reached in the 5 highest loading days and 77 percent reached in the 14 highest loading days.

This cumulative loading information emphasizes the importance of understanding the timing of loadings when considering watershed-management options. A small number of large storms transport a high percentage of the annual load. These few days with the highest loadings must be considered to provide the best chance at achieving load-reduction goals. For example, the management plan for Eagle Creek in the Driftless Area Ecoregion calls for a 50-percent reduction in upland sediment (Wisconsin Department of Natural Resources, 1990). The 3 highest loading days represent 53 percent of the annual solids load in this region (fig. 4). The reduction goal may not be met if management practices are not effective during these 3 days. Similarly, water-quality sampling used to estimate loadings in these small watersheds would need to be planned carefully to achieve an acceptable level of confidence in final results. If substantial focus is not placed on sampling or estimating concentrations during these few highest days of loading, annual loadings may be incorrectly estimated.

It is important for watershed managers to understand the seasonality in loading as well as the timeframe in which the largest storms occur. For example, a site analysis of Otter Creek in the Rural Southeastern Wisconsin Till Plains region reveals that an average of 55 percent of the annual solids loading occurred in the 7 highest loading days of the year over the 10 years that data were collected. Further examination of these 70 days reveals that 44 of them occurred within 3 months: March (15 days), April (18 days), and June (11 days). This is consistent with the timing of the three largest monthly solids loading contributions where a total of 57 percent of the annual solids loading in the Otter Creek watershed occurred in the same months: March (18 percent), April (23 percent), and June (16 percent) (Corsi and others, 2005). Management practices in this watershed would need to be effective during these 3 months to achieve load-reduction goals. Use of the cumulative distributions of daily loading (fig. 4) together with the monthly contributions (fig. 3) can provide watershed managers with a valuable tool to help choose the capacity and type of management practice needed to best achieve load-reduction goals.

\section{Variability in Loadings}

Substantial variability exists among the watersheds within each region (fig. 2). There also is substantial interannual variability for individual watersheds (fig. 2). This variability also is observed in the monthly values used to compute the averages presented in figure 3 and the cumulative distributions presented in figure 4 . Figure 5 has been included to illustrate the variability in monthly solids loadings among the eight watersheds within the Driftless Area Ecoregion. In this region, an average of 19 percent of the total solids loading is delivered as stormflow in March (fig. 3, first graph, row A). For individual watersheds, this value ranges from 7 to 45 percent (fig. 5). It also should be noted that the data from each watershed was averaged over the period of record that was available, and some watersheds have numerous years of data, but some have only a few (table 1). Results for watersheds with more years of data may provide a more accurate representation of average contributions. Collectively, this intersite and intrasite variability indicates that caution should be exercised when attempting to utilize these data for specific site applications. 

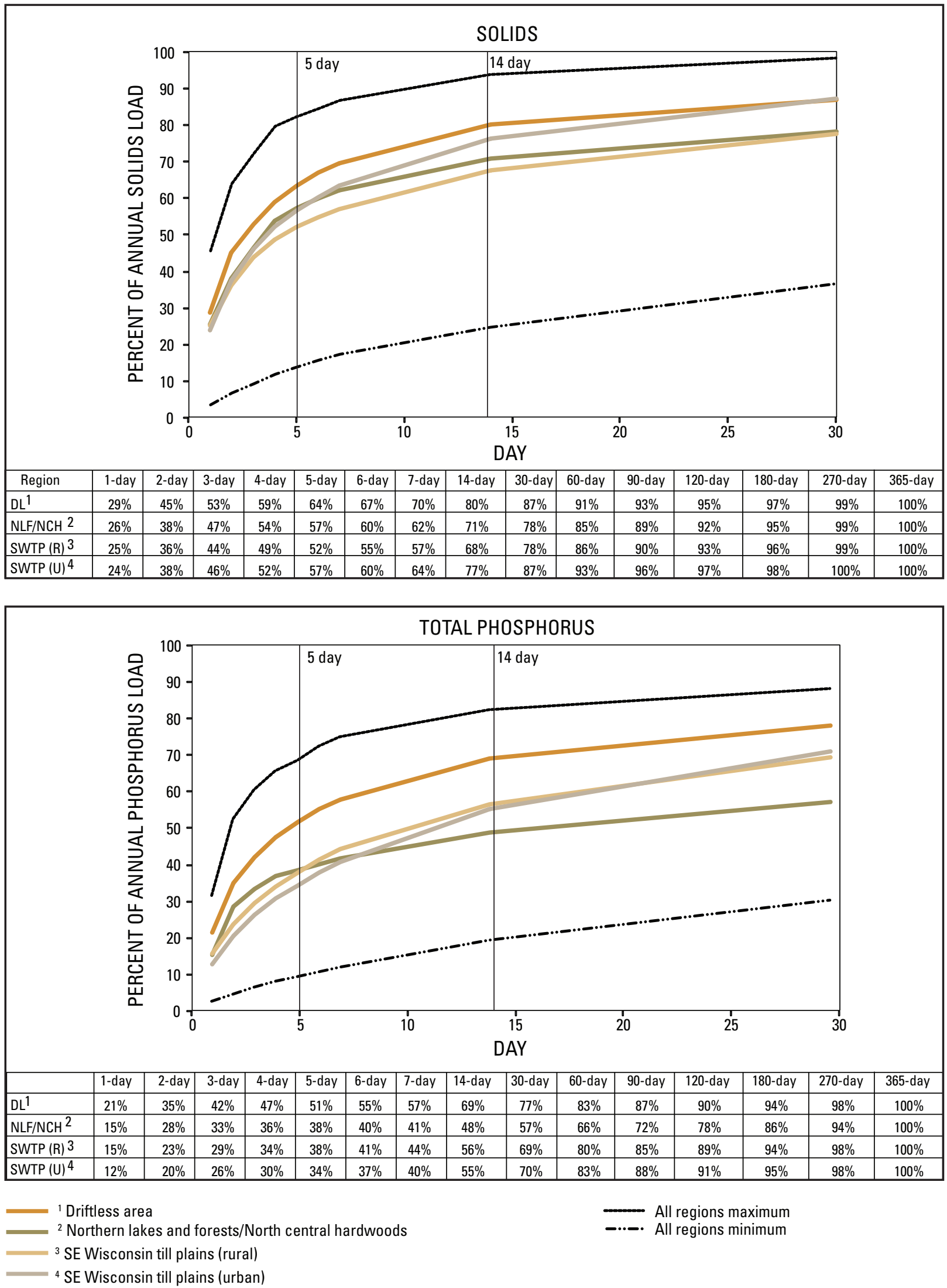

Figure 4. Cumulative distribution of ranked daily loading as a percent of annual solids and total phosphorus for selected watersheds in Wisconsin ecoregions. 


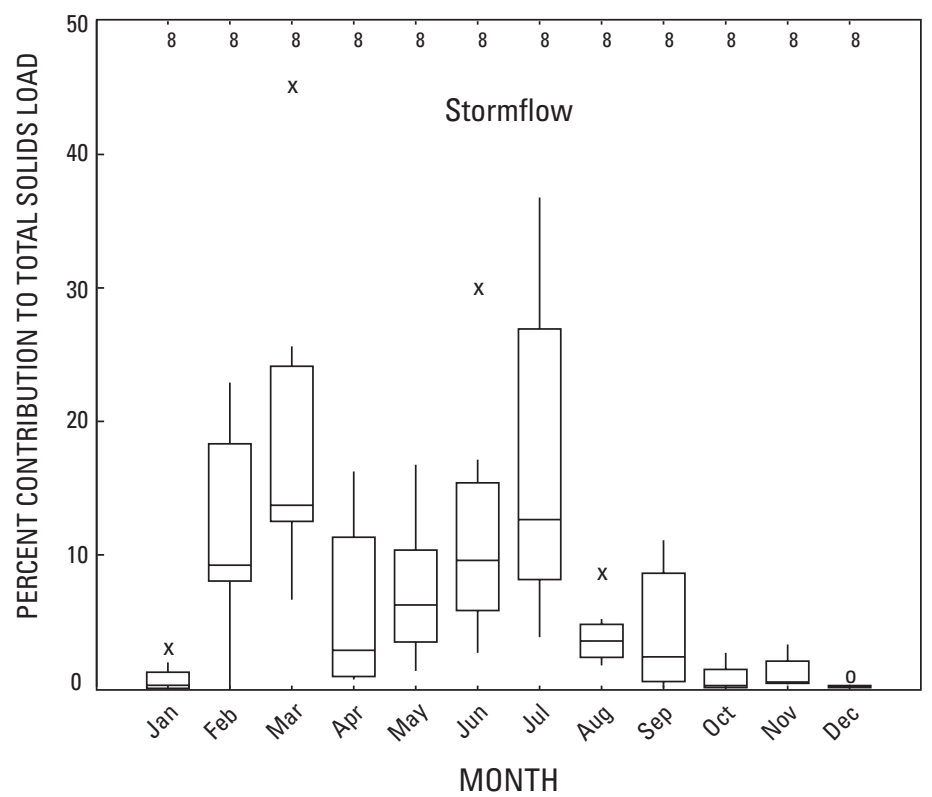

\section{EXPLANATION}

Schematic boxplot

30 number of values

$0 \quad$ upper detached

$x$ upper outside upper adjacent

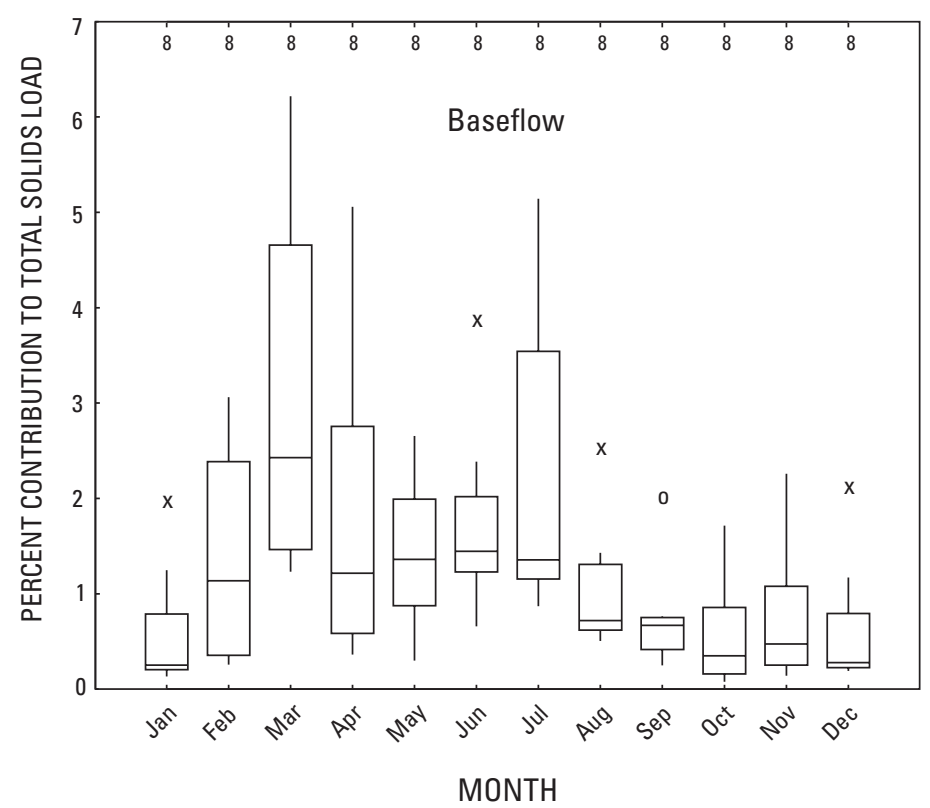

75th percentile median

25th percentile lower adjacent $x \quad$ lower outside

$0 \quad$ lower detached

Figure 5. Distribution of the percent of total solids contributed by stormflow and base flow each month for selected watersheds in the Driftless Area ecoregion of Wisconsin. 


\section{Summary and Conclusions}

To ensure the adequate design and evaluation of waterquality management practices, watershed managers need to be knowledgeable about loading trends in their watershed. The purpose of this report is to provide Wisconsin waterresource managers with information about daily, monthly, and yearly distributions of solids and total phosphorus loadings and streamflow. Loading and streamflow data for 23 small watersheds in Wisconsin were used in the generation of this report, and the data have been summarized for four regions of the State. These regions were assigned on the basis of ecoregion and land use and were as follows: the Driftless Area Ecoregion, the Northern Lakes and Forests/North Central Hardwoods region, the Rural Southeastern Wisconsin Till Plains region, and the Urban Southeastern Wisconsin Till Plains region.

Results indicate that stormflow contributions to annual load were often greater than base-flow contributions for solids and total phosphorus. The average contribution of annual solids loading by stormflow for the Driftless Area Ecoregion was 84 percent, the Northern Lakes and Forests/North Central Hardwoods region was 71 percent, the Rural Southeastern Wisconsin Till Plains region was 70 percent, and the Urban Southeastern Wisconsin Till Plains region was 90 percent. The average contributions of annual total phosphorus loading by stormflow were $72,49,61$, and 76 percent for each of the respective regions. Stormflow contributions to annual streamflow were often less than base-flow contributions. The average contributions to annual streamflow from stormflow periods were $20,23,31$, and 50 percent, respectively, for each of the regions.

Monthly summary results indicated that in all regions, the most substantial loading contributions for solids were in the late winter, spring, and early summer months, with fall and early winter contributing the smallest loadings. Total phosphorus loading showed similar patterns; however, this effect was less pronounced in the urban watersheds than it was for the rural watersheds. Similar to loading results, average monthly streamflow was greatest in late winter, spring, and early summer, with the lowest values typically in fall and early winter. Loading contributions were greater from stormflow than from base flow in all instances, except for total phosphorus loading in the Northern Lakes and Forests/ North Central Hardwoods region, which had equal or greater base-flow contribution for several months. In contrast, base flow constituted a greater percent of the total streamflow than stormflow in all rural watersheds for all regions.

The magnitude of loading for the first few highest loading days of the year indicated that a few storms each year dominated the annual loading totals for solids and total phosphorus. All four regions reached 50 percent of the annual solids loading in the 5 highest loading days and nearly 50 percent of the annual total phosphorus loading in the 14 highest loading days.

\section{Acknowledgments}

Support for this work was provided by the Wisconsin Department of Natural Resources. The authors thank all field and office personnel from the USGS and cooperating agencies who have contributed to the collection, analysis, and archival of the 31 years of data used in this report. The manuscript benefited from the suggestions made by the technical and editorial reviewers, Dale Robertson (USGS), Richard Lathrop (Wisconsin Department of Natural Resources), and Marilyn Billone (USGS). Michelle Greenwood (USGS) coordinated the publication of the report. Laura Nelson (USGS) assisted with the report illustrations. Dorothy Tepper (USGS) was the approving official.

\section{References Cited}

Corsi, S.R., Graczyk, D.J., Owens, D.W., and Bannerman, R.T., 1997, Unit-area loads of suspended sediment, suspended solids, and total phosphorus from small watersheds in Wisconsin: U.S. Geological Survey Fact Sheet 195-97, $4 \mathrm{p}$.

Corsi, S.R., Walker, J.F., Wang, Lizhu, Horwatich, J.A., and Bannerman, R.T., 2005, Effects of best-management practices in Otter Creek in the Sheboygan River Priority Watershed, Wisconsin, 1990-2002: U.S. Geological Survey Scientific Investigations Report 2005-5009, 26 p.

Garn, H.S., Olson, D.L., and Ellefson, B.R., 2001, Water resources data, Wisconsin, water year 2000: U.S. Geological Survey Water-Data Report WI-00-1, 560 p.

Graczyk, D.J., Walker, J.F., Horwatich, J.A., and Bannerman, R.T., 2003, Effects of best-management practices in the Black Earth Creek priority watershed, Wisconsin, 1984-98: U.S. Geological Survey Water-Resources Investigations Report 03-4163, 24 p.

Holmstrom, B.K., and Erickson, R.M., 1985, Water resources data, Wisconsin, water year 1984: U.S. Geological Survey Water Data Report WI-84-1, 373 p.

Holmstrom, B.K., and Erickson, R.M., 1986, Water resources data, Wisconsin, water year 1985: U.S. Geological Survey Water Data Report WI-85-1, 414 p.

Holmstrom, B.K., and Erickson, R.M., 1987, Water resources data, Wisconsin, water year 1986: U.S. Geological Survey Water Data Report WI-86-1, 402 p.

Holmstrom, B.K., and Erickson, R.M., 1988, Water resources data, Wisconsin, water year 1987: U.S. Geological Survey Water Data Report WI-87-1, 367 p. 
Holmstrom, B.K., and Erickson, R.M., 1989, Water resources data, Wisconsin, water year 1988: U.S. Geological Survey Water Data Report WI-88-1, 429 p.

Holmstrom, B.K., and Erickson, R.M., 1990, Water resources data, Wisconsin, water year 1989: U.S. Geological Survey Water Data Report WI-89-1, 449 p.

Holmstrom, B.K., Harr, C.A., and Erickson, R.M., 1983, Water resources data, Wisconsin, water year 1982: U.S. Geological Survey Water Data Report WI-82-1, 426 p.

Holmstrom, B.K., Harr, C.A., and Erickson, R.M., 1984, Water resources data, Wisconsin, water year 1983: U.S. Geological Survey Water Data Report WI-83-1, 352 p.

Holmstrom, B.K., Kammerer, P.A., and Ellefson, B.R., 1993, Water resources data, Wisconsin, water year 1992: U.S. Geological Survey Water Data Report WI-92-1, 565 p.

Holmstrom, B.K., Kammerer, P.A., and Ellefson, B.R., 1994, Water resources data, Wisconsin, water year 1993, Volume 1-St. Lawrence River Basin: U.S. Geological Survey Water Data Report WI-93-1, 311 p.

Holmstrom, B.K., Kammerer, P.A., and Ellefson, B.R., 1994, Water resources data, Wisconsin, water year 1993, Volume 2-Upper Mississippi River Basin: U.S. Geological Survey Water Data Report WI-93-2, 406 p.

Holmstrom, B.K., Kammerer, P.A., and Ellefson, B.R., 1995, Water resources data, Wisconsin, water year 1994, Volume 1 -St. Lawrence River Basin: U.S. Geological Survey Water Data Report WI-94-1, 270 p.

Holmstrom, B.K., Kammerer, P.A., and Ellefson, B.R., 1995, Water resources data, Wisconsin, water year 1994, Volume 2-Upper Mississippi River Basin: U.S. Geological Survey Water Data Report WI-94-2, 403 p.

Holmstrom, B.K., Kammerer, P.A., and Erickson, R.M., 1991, Water resources data, Wisconsin, water year 1990: U.S. Geological Survey Water Data Report WI-90-1, 592 p.

Holmstrom, B.K., Kammerer, P.A., and Erickson, R.M., 1992, Water resources data, Wisconsin, water year 1991: U.S. Geological Survey Water Data Report WI-91-1, 631 p.

Holmstrom, B.K., Olson, D.L., and Ellefson, B.R., 1996, Water resources data, Wisconsin, water year 1995: U.S. Geological Survey Water Data Report WI-95-1, 588 p.

Holmstrom, B.K., Olson, D.L., and Ellefson, B.R., 1997, Water resources data, Wisconsin, water year 1996: U.S. Geological Survey Water Data Report WI-96-1, 464 p.

Holmstrom, B.K., Olson, D.L., and Ellefson, B.R., 1998, Water resources data, Wisconsin, water year 1997: U.S. Geological Survey Water Data Report WI-97-1, 534 p.
Holmstrom, B.K., Olson, D.L., and Ellefson, B.R., 1999 , Water resources data, Wisconsin, water year 1998: U.S. Geological Survey Water Data Report WI-98-1, 534 p.

Holmstrom, B.K., Olson, D.L., and Ellefson, B.R., 2000, Water resources data, Wisconsin, water year 1999: U.S. Geological Survey Water Data Report WI-99-1, 608 p.

Homer and others, 2007, Completion of the 2001 National Land Cover Database for the Conterminous United States: Photogrammetric Engineering and Remote Sensing, v. 73, no. 4, p. 337-341.

Lathrop, R.C., 2007, Perspectives on the eutrophication of the Yahara lakes, Lake and Reservoir Management, v. 23, p. 345-365.

Lathrop, R.C., Carpenter S.R, Stow C.A., Soranno P.A., and Panuska J.C., 1998, Phosphorus loading reductions needed to control flue-green algal blooms in Lake Mendota, Canadian Journal of Fisheries and Aquatic Sciences, v. 55, no. 5 , p. $1169-1178$.

Omernik, J.M., and Gallant, A.L., 1988, Ecoregions of the Upper Midwest States: U.S. Environmental Protection Agency, Environmental Research Laboratory, EPA/600/388/037, Corvallis, Oreg., 56 p., 1 map.

Pettyjohn, W.A., and Henning, Roger, 1979, Preliminary estimate of ground-water recharge rates related streamflow and water quality in Ohio: Ohio State University Water Resources Center Project Completion Report Number 552, $323 \mathrm{p}$.

Porterfield, George, 1972, Computation of fluvial-sediment discharge: U.S. Geological Survey Techniques of WaterResources Investigations, book 3, chap. C3, 66 p.

Rantz, S.E., and others, 1982, Measurement and computation of streamflow, Volume 2-Computation of discharge: U.S. Geological Survey Water-Supply Paper 2175, p. 285-631.

Sloto, R.A., and Crouse, M.Y., 1996, HYSEP: A computer program for streamflow hydrograph separation and analysis: U.S. Geological Survey Water-Resources Investigations Report 96-4040, 46 p.

Stuntebeck, T.D., and Bannerman, R.T., 1998, Effectiveness of barnyard best management practices in Wisconsin: U.S. Geological Survey Fact Sheet 051-98, 4 p.

U.S. Environmental Protection Agency, 2003, Level III Ecoregions of the continental United States, map, scale 1:7,500,000, accessed online September 26, 2005, at http:// www.epa.gov/wed/pages/ecoregions/level iii.htm.

U.S. Geological Survey, 1977, Water resources data, Wisconsin, water year 1976: U.S. Geological Survey Water Data Report WI-76-1, 609 p. 
U.S. Geological Survey, 1978, Water resources data, Wisconsin, water year 1977: U.S. Geological Survey Water Data Report WI-77-1, 626 p.

U.S. Geological Survey, 1979, Water resources data, Wisconsin, water year 1978: U.S. Geological Survey Water Data Report WI-78-1, 501 p.

U.S. Geological Survey, 1980, Water resources data, Wisconsin, water year 1979: U.S. Geological Survey Water Data Report WI-79-1, 530 p.

U.S. Geological Survey, 1981, Water resources data, Wisconsin, water year 1980: U.S. Geological Survey Water Data Report WI-80-1, 519 p.

U.S. Geological Survey, 1982, Water resources data, Wisconsin, water year 1981: U.S. Geological Survey Water Data Report WI-81-1, 428 p.

U.S. Geological Survey, 2007, Water-resources data for the United States, water year 2006: U.S. Geological Survey Water-Data Report WDR-US-2006, accessed online August 20, 2008, at http://wdr.water.usgs.gov/.

U.S. Geological Survey, 2008, National Land Cover Database 2001 (NLCD 2001): U.S. Geological Survey, accessed online August 20, 2008, at http://www.mrlc.gov/nlcd.php.

Wang, L., Lyons, J., Kanehl, P., and Gatti, R., 1997, Influences of watershed land use on habitat quality and biotic integrity in Wisconsin streams: Fisheries, v. 22, no. 6, June 1997, p. 6-12.
Waschbusch, R.J., Olson, D.L., Ellefson, B.R., and Stark P.A., 2002, Water resources data, Wisconsin, water year 2001: U.S. Geological Survey Water-Data Report WI-01-1, $610 \mathrm{p}$.

Waschbusch, R.J., Olson, D.L., Ellefson, B.R., and Stark P.A., 2003, Water resources data, Wisconsin, water year 2002: U.S. Geological Survey Water-Data Report WI-02-1, $621 \mathrm{p}$.

Waschbusch, R.J., Olson, D.L., Ellefson, B.R., and Stark, P.A., 2004, Water resources data, Wisconsin, water year 2003: U.S. Geological Survey Water-Data Report WI-03-1, $633 \mathrm{p}$.

Waschbusch, R.J., Olson, D.L., and Marsh, S.B., 2006, Water resources data, Wisconsin, water year 2005: U.S. Geological Survey Water-Data Report WI-05-1, 982 p.

Waschbusch, R.J., Olson, D.L., Marsh, S.B., and Stark, P.A., 2005, Water resources data for Wisconsin, water year 2004: U.S. Geological Survey Water-Data Report WI-04-1, $1,071 \mathrm{p}$.

Wisconsin Department of Natural Resources, 1990, A nonpoint source control plan for the Waumandee Creek Priority watershed project: Wisconsin Department of Natural Resources report WR-274-90, 150 p. 
This page left intentionally blank 
Publishing support provided by the U.S. Geological Survey

Publishing Network, Columbus and Tacoma Publishing Service Centers

For more information concerning the research in this report, contact the Director, Wisconsin Water Science Center

U.S. Geological Survey

8505 Research Way

Middleton, Wisconsin 53562

http://wi.water.usgs.gov/ 
